Research Article

\title{
Micronucleus-Centromere Assay to Measure Ionizing Radiation Damage of Low Dose Occupational Exposure
}

Albena Staynova ${ }^{\dagger}$, Ljubomira Hadjiiska $^{\dagger}$, Valeria Hadjidekova, Rositsa Hristova *

Department of Radiobiology, National Centre of Radiobiology and Radiation Protection, 3 "Sv. G. Sofiiski" str., 1606 Sofia, Bulgaria; E-mails: a.staynova@ncrrp.org, I.hadjiiska@ncrrp.org, v.hadjidekova@ncrrp.org, r.hristova@ncrrp.org

$\dagger$ These authors contributed equally to this work.

* Correspondence: Rositsa Hristova; E-Mail: r.hristova@ncrrp.org

Academic Editor: Thomas Liehr

Special Issue: Applications of Fluorescence in Situ Hybridization

OBM Genetics

2018 , volume 2 , issue 4

doi:10.21926/obm.genet.1804043
Received: August 14, 2018

Accepted: September 25, 2018

Published: October 22, 2018

\begin{abstract}
Background: The purpose of study was to assess the cytogenetic effect of chronic low dose radiation exposure of nuclear power plant workers using the micronucleus centromere assay. This method allows the differentiation between centromere-positive micronuclei containing whole chromosome and centromere-negative micronuclei containing acentric fragment pointing to clastogenic action of ionizing radiation.

Methods: The effect of low dose occupational exposure was estimated in 32 nuclear power plant workers using in situ hybridization (FISH) with the human pancentromeric DNA probe for peripheral blood lymphocytes. Group of 17 persons from the administrative staff served as reference control group.

Results: Data on the number of micronuclei, centromere-positive micronuclei and centromere-negative micronuclei per 1000 binucleated cells for the workers were significantly higher compared with the control group $(p=0.001, p=0.01$ and $p=0.002$ respectively). No differences in the studied indicators between smokers and non-smokers
\end{abstract}

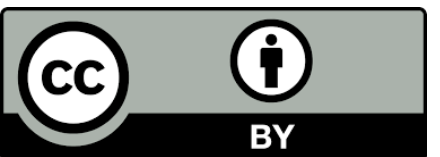

(C) 2018 by the author. This is an open access article distributed under the conditions of the Creative Commons by Attribution License, which permits unrestricted use, distribution, and reproduction in any medium or format, provided the original work is correctly cited. 
are observed. No correlation was found between age and frequency of micronuclei, centromere-positive and centromere-negative micronuclei.

Conclusions: The slight increase of the micronucleus frequency with the accumulated dose, observed in the group of workers, is mainly due to an enhanced number of centromerenegative micronuclei. Thus, the application of the $\mathrm{MN}$-centromere assay is suitable as the frequency of $\mathrm{MNCM}^{-}$is more useful marker instead of the total number of $\mathrm{MN}$.

\section{Keywords}

Occupational exposure; NPP workers; micronucleus-centromere assay

\section{Introduction}

The people working in nuclear power plants are mostly exposed to long-term exposure with low doses of ionizing radiation. These doses cannot lead to deterministic effects but can cause stochastic health consequences as a result of cell modification and subsequent cellular transformation.

Cytogenetic monitoring of nuclear power plant (NPP) workers is of great interest for better understanding the effects of low doses of ionizing radiation. Many authors reported an increased level of chromosomal aberrations among radiation workers occupationally exposed in the nuclear industry compared to control population [1-6].

When assessing low-dose radiation effects, it is important to introduce sensitive biological methods to evaluate cellular response. There is a need for suitable biomarkers that have the capability to be very specific for radiation. Cytogenetic analysis for dicentrics and translocations has been used widely for screening or biomonitoring of radiation workers, although their application has some drawbacks. The analysis of chromosome aberrations is time consuming and requires skilled microscopists examining many metaphases. Therefore, scoring of micronuclei (MN) in peripheral blood lymphocytes is an alternative method for detecting radiation exposure [7-10]. The cytokinesis-block micronucleus assay (CBMN) is faster, needs less experience and is applicable for extensive studies [11].

The main disadvantage of the CBMN assay for applying in the low-dose range of ionizing radiation is its restricted sensitivity. This is due to a higher and more varied $\mathrm{MN}$ spontaneous frequency [12].

By applying fluorescence in situ hybridization with DNA probes that bind specifically to the centromeric regions of the chromosomes [13-17], we can detect the presence or absence of a centromere signal in peripheral blood lymphocytes. Thus, we can increase the sensitivity of the $\mathrm{MN}$ assay.

In the present study, we carried out a cytogenetic study in a group of NPP workers occupationally exposed to low doses of ionizing radiation using the micronucleus-centromere assay. An age-matched group of administrative staff, with yearly doses below $1 \mathrm{mSv}$, served as reference control group. 


\section{Materials and Methods}

\subsection{Study Subjects}

To investigate the damage of low dose chronic exposure, a group of 32 NPP workers occupationally exposed to ionizing radiation was investigated by using micronucleus centromere assay. The accumulated dose was calculated during the person's entire working time at the nuclear power plant with personal dosimeters. The control population consists of 17 not exposed persons from administrative staff. The data collected from both investigated and control groups contain information about age and smoking habit. Absence of previous X-ray examinations in last three months was determined for both groups. Most of the investigated employees are males - 30 and 2 females, in age range 33-60 (47 mean age) for whole group.

Workers were classified according to their accumulated dose of radiation: $<200 \mathrm{mSv}$ and $>200$. The mean dose accumulated over the entire working time was $291.27 \mathrm{mSv}$ (range $46.87-722.96$ ). The age- and gender-matched control group comprised 16 male and 1 female in age range 32-60 (46 mean age).

\subsection{Lymphocytes Cultures}

The cytochalasine B method in lymphocytes has been introduced by Fenech [7] and described in detail. In present study, heparinized blood samples were collected by venipuncture $(9 \mathrm{ml}$ blood in sterile vacutainers). Within the first 24 after blood sampling, cultures, in the presence of Phytohaemagglutinin (Gibco by life technologies) as mitogen, were initiated and incubated for 44 hours at $37^{\circ} \mathrm{C}$. Then, Cytochalasine B (Sigma) was added at concentration $6 \mu \mathrm{g} / \mathrm{ml}$ to block cytokinesis. After an incubation period of $72 \mathrm{~h}$, the cells were collected and fixed by standard procedure. The dropped slides were stored at $-20^{\circ} \mathrm{C}$ before in situ hybridization with the centromeric DNA probe.

\subsection{In Situ Hybridization with the Centromeric DNA Probe}

In situ hybridization was performed according to the protocol described by Pinkel et al [18]. FITC labeled DNA human pancentromeric probe (Cambio, UK) was used. The slides were incubated with two antibodies (rabbit anti-FITC and FITC goat-anti rabbit immunoglobulin) for detection of hybridization signal. The fluorescent dye 4',6-Diamidine-2'-phenylindole dihydrochloride (DAPI, Sigma) in anti-fade solution was used to counter-stain the DNA. The hybridized probe appears as yellow spots. Depending on the presence of fluorescent signals in $\mathrm{MN}$, they were defined as centromere positive $\left(\mathrm{MNCM}^{+}\right)$or centromere negative $\left(\mathrm{MNCM}^{-}\right)$.

\subsection{Scoring Criteria and Statistical Analysis}

In the FISH study, MN were examined for the presence of centromeres under an Olympus BX41 microscope with 1000x magnification. The MN frequencies were scored according to the criteria set by Fenech [19]. Between 1000 and 2000 binucleated cells were scored per individual by two independent investigators. The results are expressed as the total number of $\mathrm{MN} \mathrm{MNCM}^{+}$and $\mathrm{MNCM}^{-}$per 1000 binucleated (BN) cells. Data from all investigated groups, as well as, influence of age, accumulated dose and smoking habit were estimated by IBM SPSS Statistics 19. 
Nonparametric methods of statistical analysis, Mann-Whitney Test and Spearman's correlation, were applied.

Before blood collection, an informed consent was obtained from all donors. Peripheral blood samples were collected by venipuncture in heparinized tubes during the periodic medical examination.

\section{Results}

Micronucleus-centromere assay was performed in peripheral blood lymphocytes of 32 nuclear power plant workers (Kozloduy, Bulgaria) and 17 administrative staff controls.

Data on the number of $\mathrm{MN}, \mathrm{MNCM}^{+}$and $\mathrm{MNCM}^{-}$per 1000 binucleated cells for the controls and the workers with different accumulated doses are presented together with the number of investigated subjects in Table1. Values of the same indicators, obtained by subdivision of smokers and non-smokers, are also included. Within the brackets are represented the values of the standard deviations.

The average number of $\mathrm{MN}$ in the control group is 11.65 (5.45) with a range of 5.5 to $24 \mathrm{MN}$ per 1000 binucleated cells. Our results correlate with previously published data for a Bulgarian population with spontaneous frequency of 12.94 (6.99) ranging from 1 to $26.6 \mathrm{MN}$ [20]. Other authors have reported a spontaneous frequency ranging from 2 to $36 \mathrm{MN}$ per $1000 \mathrm{BN}$ cells [21].

The average number of $\mathrm{MN}$ in the group of workers is $18.80(9.40)$ with a range of 8 to $41 \mathrm{MN}$ per 1000 binucleated cells. The increased frequency of detected MN in NPP workers is statistically significant compared with the control group $(p=0.001$,$) and it is mainly due to an enhanced$ number of $\mathrm{MNCM}^{-}$.

In the control group, the ratio $\mathrm{MNCM}^{+} / \mathrm{MNCM}^{-}$is: $46.21 \% / 53.79 \%$ (Fig1). The difference between frequency of $\mathrm{MNCM}^{+}$and $\mathrm{MNCM}^{-}$is insignificant $(\mathrm{p}=0.37)$. In the group of workers, the ratio is respectively: $42.56 \% / 57.44 \%$ (Fig2). The difference is statistically reliable ( $p=0.03$ ).

When compared with the control group, workers with accumulated doses $<200 \mathrm{mSv}$ showed significant increase of $\mathrm{MN}$ and $\mathrm{MNCM}^{-}$frequency ( $\mathrm{p}=0.02$ and $\mathrm{p}=0.035$ respectively), but not for $\mathrm{MNCM}^{+}$frequency $(p=0.07)$. Workers with accumulated doses $>200 \mathrm{mSv}$ showed a statistically significant elevation in $\mathrm{MN}, \mathrm{MNCM}^{+}$and $\mathrm{MNCM}^{-}$frequency $(\mathrm{p}=0.002, \mathrm{p}=0.01$ and $\mathrm{p}=0.002$ respectively) in compare with controls.

In the group of workers with doses $>200 \mathrm{mSv}$, there was a tendency of enhancement in the frequency of MN compared to the workers with doses $<200 \mathrm{mSv}$. The difference is insignificant and is due to an enhanced number of $\mathrm{MNCM}^{-}$(Fig3).

The distribution of smokers and non-smokers was approximately equal in both groups (56\% and $53 \%$ smokers in workers and controls, respectively). We observed no correlation between induced $M N$ frequency and smoking habit $(p=0.96$ and $p=0.7$ for workers and controls, respectively).

There is no influence of the age on the studied indicators in the observed groups. For the control group, the Spearman's coefficient of correlation was $r=0.2, r=0.2$ and $r=0.16$ for the MN, MNCM+ and MNCM- respectively. In workers group the Spearman's coefficient was $r=0.19, r=0.11$ and $r=0.26$ respectively for the same indicators. The lack of correlation coincide with observed data in the Bulgarian control population [20]. 


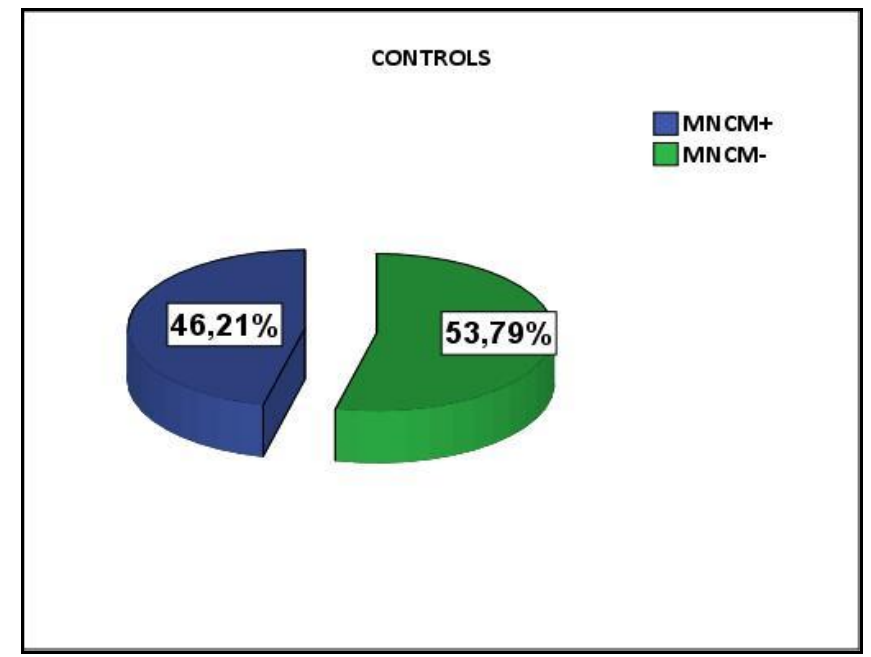

Figure $1 \mathrm{MNCM}^{+} / \mathrm{MNCM}$ - ratio in control administrative stuff.

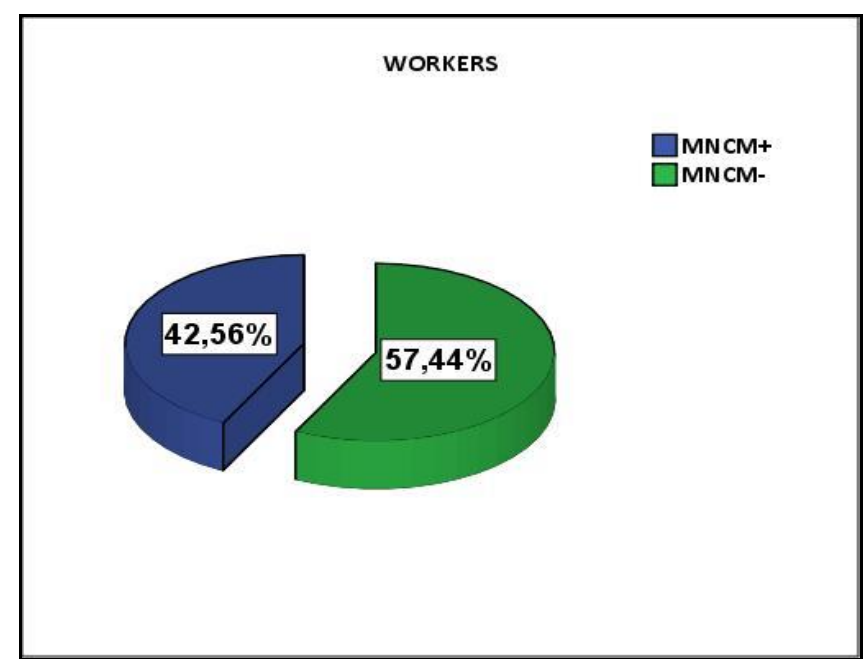

Figure $2 \mathrm{MNCM}^{+} / \mathrm{MNCM}^{-}$ratio in NPP workers.

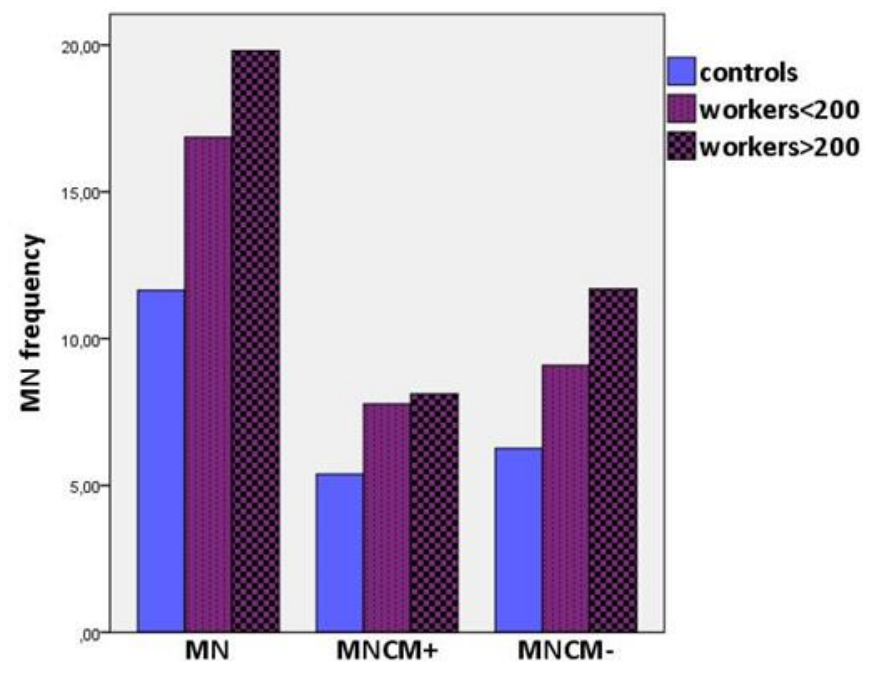

Figure 3 Comparison of $\mathrm{MN}, \mathrm{MNCM}^{+}$and $\mathrm{MNCM}^{-}$frequencies per $1000 \mathrm{BN}$ cells for the groups of controls and workers with accumulated doses $<200 \mathrm{mSv}$ and $>200 \mathrm{mSv}$. 
Table 1 Comparison of the mean number of $\mathrm{MN}, \mathrm{MNCM}^{+}$and $\mathrm{MNCM}^{-}$per 1000 binucleated cells between the exposed and control population.

\begin{tabular}{|c|c|c|c|c|c|}
\hline & & MN\%o (SD) & $\mathrm{MNCM}^{+} \%$ (SD) & $\mathrm{MNCM}^{-} \%$ (SD) & \\
\hline \multirow{3}{*}{ Controls } & Total & $11,65(5,45)$ & $5,38(2,81)$ & $6,26(2,86)$ & $\mathrm{n}=17$ \\
\hline & smokers & $12,22(6,42)$ & $5,94(3,44)$ & $6,28(3,16)$ & $n=9$ \\
\hline & $\begin{array}{l}\text { non- } \\
\text { smokers }\end{array}$ & $11,00(4,47)$ & $4,75(1,91)$ & $6,25(2,69)$ & $n=8$ \\
\hline \multirow{3}{*}{ Workers } & Total & $18,80(9,40)$ & $8,00(4,56)$ & $10,80(5,51)$ & $n=32$ \\
\hline & smokers & $\begin{array}{l}19,06 \\
(10,13)\end{array}$ & $7,61(4,70)$ & $11,44(6,14)$ & $n=18$ \\
\hline & $\begin{array}{l}\text { non- } \\
\text { smokers }\end{array}$ & $18,46(8,73)$ & $8,50(4,49)$ & $9,96(4,68)$ & $n=14$ \\
\hline \multirow{3}{*}{$\begin{array}{c}\text { Workers }<200 \\
\mathrm{mSv}\end{array}$} & Total & $16,86(7,82)$ & $7,77(4,63)$ & $9,09(3,79)$ & $n=11$ \\
\hline & smokers & $\begin{array}{l}24,50 \\
(17,68)\end{array}$ & $10,75(10,25)$ & $13,75(7,42)$ & $n=2$ \\
\hline & $\begin{array}{l}\text { non- } \\
\text { smokers }\end{array}$ & $15,17(4,42)$ & $7,11(3,31)$ & $8,06(2,10)$ & $n=9$ \\
\hline \multirow{3}{*}{$\begin{array}{c}\text { Workers }>200 \\
\text { mSv }\end{array}$} & Total & $\begin{array}{l}19,81 \\
(10,16)\end{array}$ & $8,12(4,63)$ & $11,69(6,12)$ & $n=21$ \\
\hline & smokers & $18,38(9,54)$ & $7,22(4,07)$ & $11,16(6,19)$ & $n=16$ \\
\hline & $\begin{array}{l}\text { non- } \\
\text { smokers }\end{array}$ & $\begin{array}{l}24,40 \\
(11,84)\end{array}$ & $11,00(5,62)$ & $13,40(6,27)$ & $n=5$ \\
\hline
\end{tabular}

$\mathrm{SD}$ - standard deviation; $\mathrm{n}$ - number of investigated subjects

\section{Discussion}

There is a correlation between radiation exposure, induction of chromosomal damages and subsequent malignancy. An enhanced level of chromosomal aberrations compared to control populations can be detected after irradiation with doses above 100-200 mSv. Nevertheless, the relation between an increased incidence of chromosomal aberrations in healthy individuals and subsequent malignancy was established [22-24]. The increased frequency of MN resulting from chromosomal damages also relates to the elevated risk of subsequent carcinogenesis [25].

The occupational exposure of NPP workers is a prolonged exposure to low doses and low dose rates. Cytogenetic monitoring of occupationally exposed individuals in nuclear industry showed an enhanced frequency of chromosomal aberrations, although annually received doses are lower than the limited values $[1-3,26,27]$. All of these authors reported an increased frequency of chromosomal damage in persons working in nuclear power plants, nuclear submarines, uranium mining and radioactive waste repositories, although the accumulated doses were less than the dose limit of $50 \mathrm{mSv}$ per year for radiation workers during the cited studies. These studies indicate that nuclear industry is associated with some mutagenic risk.

In some cases, there is a relationship between the intended effect and the accumulated dose, as well as, its relationship to additional harmful factors. There is an effect of age, gender, diet and 
lifestyle on micronucleus frequency in human peripheral blood lymphocytes [28]. In our study, we

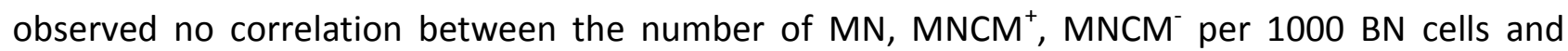
ageing, which is probably due to the small number of subjects studied in each group. No influence of the tobacco smoking on the studied indicators was found. The results of the impact of smoking on the MN frequency in various studies are controversial [29]. The correlation between the yield of $\mathrm{MN}$ and gender was not performed because of the small number of females in each group (two females in workers group and one in controls).

It is well known that ionizing radiation has a clastogenic action (induces predominantly chromosome breakage) and less aneugenic action. Therefore, most of the radiation induced MN result from acentric chromosome fragments which in turn arise from chromosome breakage. To a much lesser extent the number of radiation induced $\mathrm{MN}$ originate from whole chromosomes that fall behind during the cell division.

Application of micronucleus-centromere assay let us differentiate between centromerepositive and-negative $\mathrm{MN}[30]$.

The studied subjects in the present work are employees in the only nuclear power plant in Bulgaria - "Kozloduy", which is situated on the North Bulgarian border on the Danube riverbank.

Personal occupational exposure to ionizing radiation is under regular control. Irradiation of the examined group in this study is mainly external, and mainly $\gamma$-radiation, with a negligible exposure to $\beta$-radiation and neutrons. Individual doses are measured monthly by film and thermoluminescent dosimeters.

The personal doses in the group under study were accumulated during a period of 10 to 40 years. Average length of entire working time in the group with doses $<200 \mathrm{mSv}$ is 19.8 years, which is significantly less when compared with workers with doses $>200 \mathrm{mSv}-26$ years $(p=0.02)$.

The results obtained showed a significant increase in the frequency of $\mathrm{MN}$ in peripheral blood lymphocytes of exposed workers compared to controls from the administrative staff. When we compared the $\mathrm{MNCM}^{+}$and $\mathrm{MNCM}^{-}$frequencies between the control and worker groups according the accumulated doses, the most susceptible increase with the dose received was observed in the incidence of $\mathrm{MNCM}^{-}$. This elevated centromere-negative micronucleus yield is responsible for the enhanced frequency of $\mathrm{MN}$ with accumulated dose, pointing to the clastogenic action of ionizing radiation.

Accumulated doses in the workers group are in a broad range of $46.87-722.96 \mathrm{mSv}$. However, doses received by workers are mainly in the range of 200 to $400 \mathrm{mSv}$. Only $16 \%$ of the subjects surveyed have accumulated doses above $400 \mathrm{mSv}$. This, as well as, the small number of subjects, does not allow for a correct tracking of the effect of the dose.

\section{Conclusions}

When compared with the control group, workers with accumulated doses up to $200 \mathrm{mSv}$ showed no statistically significant increase in $\mathrm{MNCM}^{+}$frequency $(p=0,07)$, whereas difference in the number of $\mathrm{MNCM}^{-}$per $1000 \mathrm{BN}$ cells between mentioned groups is statistically significant. The observed enhancement in the frequency of $\mathrm{MNCM}^{-}$points to the possible clastogenic effect of ionizing radiation. Thus, for biomonitoring or screening of large groups of workers exposed to low doses of ionizing radiation, the application of the $\mathrm{MN}$-centromere assay is suitable as the frequency 
of $\mathrm{MNCM}^{-}$is more useful marker instead of the total number of $\mathrm{MN}$, which are non-specific for radiation exposure.

\section{Author Contributions}

Albena Staynova and Ljubomira Hadjiiska contributed equally to this work.

\section{Funding}

This study was performed by grants from the NPP "Kozloduy", Sofia, Bulgaria, project nos. 010857,010858 and 010859.

\section{Competing Interests}

The authors have declared that no competing interests exist.

\section{References}

1. Bauchinger M, Kolin-Gerresheim J, Schmid E, Dresp J. Chromosome analyses of nuclear-power plant workers. Int J Radiat Biol Relat Stud Phys Chem Med, 1980; 38: 577-581.

2. Lloyd D, Purrott R, Reeder E.The incidence of unstable chromosome aberrations in peripheral blood lymphocytes from unirradiated and occupationally exposed people. Mutat Res. 1980; 72: 523-532.

3. Tawn E, Binks K. Binks. A cytogenetic study of radiation workers: The influence of dose accumulation patterns and smoking. Radiat Prot Dosimetry. 1989; 28: 173-180.

4. Al-Sabti K, Lloyd D, Edwards A, Stegnar P. A survey of lymphocyte chromosomal damage in Slovenian workers exposed to occupational clastogens. Mutat Res Genet Toxicol. 1992; 280: 215-223.

5. Braselmann H, Schmid E, Bauchinger M. Chromosome aberrations in nuclear power plant workers: the influence of dose accumulation and lymphocyte life-time. Mutat Res. 1994; 306: 197-202.

6. Hristova R, Hadjidekova V, Grigorova M, Nikolova T, Bulanova M, Popova L, et al. Chromosome analysis of nuclear power plant workers using fluorescence in situ hybridization and Giemsa assay. J Radiat Res. 2013; 54: 832-839.

7. Fenech M, Morley AA. Measurement of micronuclei in lymphocytes. Mutat Res. 1985; 147 : 29-36.

8. Venkatachalam P, Paul SF, Mohankumar MN, Prabhu B, Gajendiran N, Jeevanram R. Doseresponse curve for translocation frequency with single pair of painted chromosome. A comparison with dicentric and micronuclei frequency. Radiat Prot Dosimetry. 2000; 87: 101108.

9. Prosser J, Moquet J, Lloyd D, Edwards A. Radiation induction of micronuclei in human lymphocytes. Mutat Res. 1988; 199: 37-45.

10. Ramalho A, Sunjevaric I, Natarajan A. Use of the frequencies of micronuclei as quantitative indicators of X-ray-induced chromosomal aberrations in human peripheral blood lymphocytes: Comparison of two methods. Mutat Res Letters, 1988; 207: 141-146. 
11. Thierens, H. Inter-laboratory comparison of cytogenetic endpoints for the biomonitoring of radiological workers. Int J Radiat Biol. 1999; 75: 23-34.

12. Bonassi S, Fenech M, Lando C, Lin Yp, Ceppi M, Chang WP, et al. Human micronucleus project: international database comparison for results with the cytokinesis-block micronucleus assay in human lymphocytes: I. Effect of laboratory protocol, scoring criteria, and host factors on the frequency of micronuclei. Environ Mol Mutagen. 2001; 37: 31-45.

13. Becker $P$, Scherthan $H$, Zankl $H$. Use of a centromere-specific DNA probe $(p 82 H)$ in nonisotopic in situ hybridization for classification of micronuclei. Genes Chromosomes Cancer. 1990; 2: 59-62.

14. Miller B, Werner T, Weier $\mathrm{H}-\mathrm{U}$, Nüsse $\mathrm{M}$. Analysis of radiation-induced micronuclei by fluorescence in situ hybridization (FISH) simultaneously using telomeric and centromeric DNA probes. Radiat Res. 1992; 131: 177-185.

15. Farooqi Z, Darroudi F, Natarajan A. The use of fluorescence in situ hybridization for the detection of aneugens in cytokinesis-blocked mouse splenocytes. Mutagenesis. 1993; 8: 329334.

16. Norppa H, Renzi L, Lindholm C. Detection of whole chromosomes in micronuclei of cytokinesis-blocked human lymphocytes by antikinetochore staining and in situ hybridization. Mutagenesis. 1993; 8: 519-525.

17. Migliore L, Cocchi L, Scarpato R. Detection of the centromere in micronuclei by fluorescence in situ hybridization: its application to the human lymphocyte micronucleus assay after treatment with four suspected aneugens. Mutagenesis.1996; 11: 285-90.

18. Pinkel D, Straume T, Gray J. Cytogenetic analysis using quantitative, high-sensitivity, fluorescence hybridization. Proc Natl Acad Sci U S A. 1986; 83: 2934-2938.

19. Fenech M, Bonassi S, Turner J, Lando C, Ceppi M, Chang WP, et al. Intra- and inter-laboratory variation in the scoring of micronuclei and nucleoplasmic bridges in binucleated human lymphocytes. Results of an international slide-scoring exercise by the HUMN project. Mutat Res. 2003; 534: 45-64.

20. Hadjidekova V, Hadjiiska LP, Hristova R. Chromosome aberrations and micronuclei in peripheral blood lymphocytes of a healthy individuals control group of Bulgarian population. 2007; 20-25.

21. Bauchinger $\mathrm{M}$, Braselmann $\mathrm{H}$. Use of micronuclei in biological dosimetry of absorbed radiation dose, in chromosomal aberrations: Basic and applied aspects. G. Obe and A.T. Natarajan, Editors. 1990; Springer Berlin Heidelberg: Berlin, Heidelberg. 202-211.

22. Brögger A, Hagmar L, Hansteen I-L, Heim S, Högstedt B, Knudsen L, et al. A Nordic data base on somatic chromosome damage in humans. Nordic study group on the health risk of chromosome damage. Mutat Res. 1990; 241: 325-337.

23. Hagmar L, Bonassi S, Strömberg U, Mikoczy Z, Lando C, Hansteen I-L, et al. Cancer predictive value of cytogenetic markers used in occupational health surveillance programs: a report from an ongoing study by the European Study Group on Cytogenetic Biomarkers and Health. Mutat Res. 1998; 405: 171-178.

24. Hagmar L, Strömberg U, Bonassi S, Hansteen I-L, Knudsen LE, Lindholm C, et al. Impact of types of lymphocyte chromosomal aberrations on human cancer risk: results from Nordic and Italian cohorts. Cancer Res. 2004; 64: 2258-2263. 
25. Bonassi S, Znaor A, Ceppi M, Lando C, Chang WP, Holland N, et al. An increased micronucleus frequency in peripheral blood lymphocytes predicts the risk of cancer in humans. Carcinogenesis, 2007; 28: 625-631.

26. Evans H, Buckton K, Hamilton G, Carothers A. Radiation-induced chromosome aberrations in nuclear-dockyard workers. Nature. 1979; 277: 531-534.

27. Tanaka K, Tchaijunusova NJ, Takatsuji T, Gusev BI, Sakerbaev AK, Hoshi M, et al. High incidence of micronuclei in lymphocytes from residents of the area near the Semipalatinsk nuclear explosion test site. J Radiat Res. 2000; 41: 45-54.

28. Fenech M, Bonassi S. The effect of age, gender, diet and lifestyle on DNA damage measured using micronucleus frequency in human peripheral blood lymphocytes. Mutagenesis. 2011; 26: 43-49.

29. Bonassi S, Neri M, Lando C, Ceppi M, Lin Y-p, Chang WP, et al. Effect of smoking habit on the frequency of micronuclei in human lymphocytes: results from the Human MicroNucleus project. Mutat Res. 2003; 543: 155-166.

30. Kirsch-Volders M, Elhajouji A, Cundari E, Van Hummelen P. The in vitro micronucleus test: a multi-endpoint assay to detect simultaneously mitotic delay, apoptosis, chromosome breakage, chromosome loss and non-disjunction. Mutat Res. 1997; 392: 19-30.

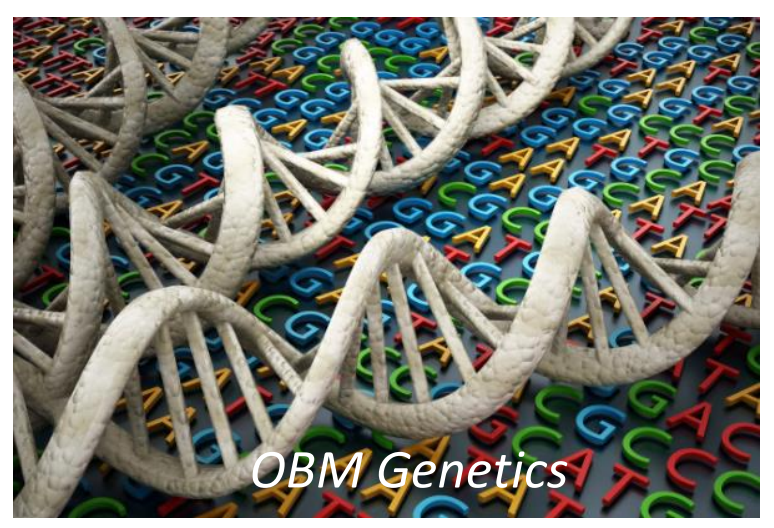

Enjoy OBM Genetics by:

1. Submitting a manuscript

2. Joining in volunteer reviewer bank

3. Joining Editorial Board

4. Guest editing a special issue

For more details, please visit: http://www.lidsen.com/journals/genetics 